\title{
State Participation in Space Activities: Some Legal Approaches and Implications
}

\author{
Iryna Ryzhenko
}

Ph.D. in Law, Associate Professor, Kherson State University

(Kherson, Ukraine)

E-mail: Rigenko_Irina@ukr.net

https://orcid.org/0000-0002-9208-2132

\section{Olena Halahan}

Senior lecturer, Kherson State Maritime Academy (Kherson, Ukraine)

E-mail: olena_halahan@ukr.net

https://orcid.org/0000-0001-8392-6965

\section{Участь держави в космічній діяльності: правові підходи та наслідки}

\begin{abstract}
Риженко, Ірина Миколаївна
Кандидат юридичних наук, доцент, завідувач кафедри адміністративного і господарського права та правоохоронної діяльності Херсонського державного університету (Херсон, Україна)
\end{abstract}

\section{Галаган, Олена Ярославівна}

Старший викладач кафедри економіки та морського права Херсонської державної морської академії (Херсон, Україна)

\begin{abstract}
Еволюиія: у статті здійснюється аналіз норм міжнародного права, щуо відносяться до відповідальності держави та інших суб'єктів міжнародного права під час здійснення таких видів космічної діяльності як дистанційне зондування Землі із космосу, забезпечення супутникового мовлення, попередження та ліквідаиії надзвичайних ситуаиій, використання ядерних джерел енергіі у космічному просторі. Досліджуються питання міжснародної правосуб'єктності держави у реалізаиї прикладних видів космічної діяльності, розглядаються такі форми міжнародно-правової відповідальності держави як політична і матеріальна. Особливу увагу в статті приділено
\end{abstract}

(C) Ryzhenko, Iryna, 2018

(C) Halahan, Olena, 2018 
State Participation in Space Activities: Some Legal Approaches and Implications

by Iryna Ryzhenko and Olena Halahan

новому етапу розвитку космічних технологій. У иьому зв'язку в загальному вигляді аналізуються національні законодавства деяких космічних краӥн, які регулюють питання освоєння космосу як для потреб науки, так і для потреб національної оборони ичих країн. У дослідженні розвивається ідея свободи космосу, яка не може слугувати підставою для ведення діяльності, шуо має на меті порушення принц̧ипу поваги державного суверенітету, адже під час використання супутників можуть зачіпатися суверенні права і законні інтереси іниих держав. Розглядається питання поєднання приничиу свободи космічної діяльності із принияиом суверенітету держав над своєю територією, зокрема над природними ресурсами. При изьому визначається, щьо ДзЗ чужої територї є порушенням принципу суверенітету країн, і особливо може мати негативні наслідки для краӥн, шуо розвиваються. Аналіз космічного законодавства ряду краӥн дає можливість зробити висновок, щуо існуючий стан із правовою регламентацією міжнародно-правової відповідальності країн за наслідками космічної діяльності, найчастіше визначається можливостями і бажанням краӥн розширювати власну космічну діяльність, та бажанням підтримувати приватних підприємств та їх бізнесу, пов'язаного з космічною діяльністю. Таке дослідження сприятиме розробці систематичного підходу до міжнародно-правового регулювання діяльності держав у сфері оформлення оренди космічної станції за зразком договору оренди офісу, космічного туризму, видобутку на астероїда тощзо.

Ключові слова: міжнародна правосуб'єктність держави, відповідальність, прикладні види космічної діяльності, відшкодування збитків, дистаниійне зондування Землі, ядерні джерела енергії, супутникові технології, геостаціонарна орбіта, право власності на небесні тіла, Угода про відкритий космос.

Received: August 22, 2018; accepted: September 24, 2018

Advanced Space Law, Volume 2, 2018: 50-62.

https://doi.org/10.29202/asl/2018/2/7

\section{Постановка проблеми}

У наш час весь світ усвідомив значимість космосу як джерела добробуту і забезпечення безпеки. Питання правового регулювання космічної діяльності завжди було об'єктом дослідження ряду вчених, на законодавчому рівні космічна діяльність регулюється вже більше ніж двома десятками країн. Що стосується проблеми міжнародно-правової правосуб'єктності держави, та особливо іiі відповідальності за наслідки космічної діяльності, то це питання ставало предметом не лише правових, але і політичних дискусій, після яких створювалися відповідні закони та продовжувалися різного роду дебати між представниками космічних держав. Законодавство, що регулює космічну діяльність країн має певні відмінності, викликані рівнем розвитку космічної галузі у них. Процес комерціалізації космосу постійно вимагає рішучих дій не лише від суб'єктів публічного права, але і від усіх інших зацікавлених у цьому фізичних та юридичних осіб, тому логічно постає питання доцільності обмеження розміру відповідальності за негативні наслідки використання прикладних видів космічної діяльності, що у свою чергу сприятиме більш активній участі у ній підприємств приватного сектора. Іншими словами, популярними стають ідеї необхідності відшкодування збитків при аваріях, коли величина їх розміру перевищує певну суму. 
Актуальність статті зумовлена відсутністю комплексних досліджень, присвячених питанням міжнародної правосуб'єктності держави у сфері використання прикладних видів космічної діяльності. Недостатньо розглянутими залишаються питання відповідальності суб'єктів міжнародного права за негативні наслідки використання прикладних видів космічної діяльності. При цьому аналіз ряду досліджень щодо міжнародно-правового регулювання космічної галузі показує, що співпраця держав в цій галузі має досить серйозне підгрунтя та юридичну базу, що включає комплекс конвенцій, угод, пактів, розроблених як на універсальному, так і на регіональному рівнях.

Метою дослідження є здійснення комплексного правового аналізу стану і перспектив розвитку норм міжнародного права, що відносяться до відповідальності держав та інших суб’єктів міжнародного права під час здійснення таких прикладних видів космічної діяльності як дистанційне зондування Землі із космосу, забезпечення супутникового мовлення, попередження та ліквідації надзвичайних ситуацій, використання ядерних джерел енергії у космічному просторі.

\section{Виклад основного матеріалу}

Космічну діяльність постійно супроводжують різного роду ризики, тому цілком слушним є питання, яке постає перед рядом космічних країн: продовжувати іiі здійснювати і свідомо ризикувати або обмежитися існуючим станом і користуватися існуючими надбаннями. У цьому контексті логічним важливим є питання щодо основоположної охоронної функції держави, спрямованої на забезпечення цивільної безпеки. Ця турбота держави проявляється у тому, що надаючи дозвіл комерційним організаціям займатися прикладними видами космічної діяльності, вона має належним чином подбати про те, щоб забезпечити контроль і державний нагляд за діяльністю підприємств, які займаються запусками ракет і супутників у космос, що вже є апріорі джерелом підвищеної небезпеки.

Історично космічні розробки переживали ряд етапів. Перший космічний період проходив у період з 1957 р. до1972 р. в умовах суперництва між США та СРСР, яке призвело до використання космосу у військових цілях і першої в світовій історії висадки людини на Місяць [von Bencke, 1997: 205]. Під час другого періоду, який проходив 3 1973 р. і приблизно до 1990 рр., разом з Європейським космічним агентством, незалежні програми польотів в космос розвивали вже Японія, Китай, Індія та інші країни, після чого вже було розгорнуто повномасштабне комерційне використання космічного простору, за якого приватні підприємства розпочали надавати послуги запуску і експлуатації штучних супутників для забезпечення зв'язку, мовлення та дистанційного зондування. Третій космічний період розпочався з 1990 р. і тривав до 2006 р., і характеризувався появою компактних космічних апаратів відносно невисокій вартості при істотно збільшеній функціональності, у результаті чого різко збільшилася кількість суб'єктів космічної діяльності, частина 3 яких розпочала надавати послуги з обробки космічних відомостей тим, хто не має в своєму розпорядженні власних супутників [Handbook, 2015: 38-43]. Нині людство знаходиться у четвертому періоді космічного розвитку і до найважливіших проблем правового регулювання космічної галузі відносяться питання міжнародно-правової відповідальності суб’єктів космічної галузі [Сэцуко, 2017].

Формування стратегічного космічного потенціалу США та Китаю та стрімкий злет у сфері високотехнологічних виробництв $є$ подібним до ситуації, що виникла у 
зв'язку із запуском першого штучного супутника Землі та початком космічної гонки між США і СРСР, викликавши зростання рівня технологічних можливостей, недосяжного для інших. Тому є ймовірність, що відставання інших країн в цій конкуренції стане проблемою, яка позначиться на їх загальному технологічному потенціалу.

Основні правила поведінки в космічному просторі встановлює Договір про принципи діяльності держав по дослідженню і використанню космічного простору, включаючи Місяць та інші небесні тіла 1967 р. Разом зі свободу його досліджень і використання, забороною на розміщення зброї масового знищення цей документ встановлює особливі правила, відповідно до яких держава несе безпосередню міжнародну відповідальність по покриттю збитків постраждалій країні та на підставі режиму ліцензування має забезпечити нагляд за дотриманням приватними підприємствами норм, передбачених міжнародним законом. Національні законодавства про космос мають на меті не лише забезпечити правове регулювання космічних країн в освоєнні космосу для потреб науки, але і покликаний сприяти національній обороні цих країн.

Нині космічні технології розвиваються надзвичайно швидко і якщо раніше для запуску супутника було необхідно принаймні п’ять років, то тепер для підготовки мінісупутника достатньо навіть чотирьох місяців. Актуальними проблемами залишаються такі як боротьба з космічним сміттям та порятунок астронавтів, які потрапили в біду. Проте сьогодення пропонує до розгляду наступні амбітні плани сучасних космічних юристів, які включають в себе оформлення оренди космічної станції за зразком договору оренди офісу, космічний туризм, видобуток на астероїдах та розробку правил при контакті з позаземним життям.

Питання міжнародної правосуб'єктності держави у космічній діяльності викликає ряд дискусій, оскільки Договір про космос 1967 року по суті є єдиним по-справжньому укладеним міжнародним документом, проте він містить деяку правову прогалину, яка дає змогу деяким бажаючим навіть претендувати на небесні тіла. Зокрема, у 1980 р. житель США Деніс Хоуп направив до ООН запит, у якому виявив намір привласнити Місяць. Деніс Хоуп посилався на те, що Міжнародний Договір про космос визначає, що в космічному просторі кожна країна може вільно здійснювати свою діяльність, проте у ньому була виражена заборона претендувати на небесні тіла державам, проте про заборону для суб'єктів приватного права мова не йшла. Як результат, компанія Хоупа отримала багатомільйонні прибутки за продаж ділянок на Місяці всім бажаючим. Намагаючись забезпечити для своїх клієнтів право власності на придбані ділянки, Хоуп навіть заснував демократичну республіканську націю «Галактичний уряд» у 2001 році, а у 2004 - навіть підготував конституцію для неї. Звичайно, Хоуп був не єдиним, хто мав бажання продавати ділянки на Місяці, проте він подавав до суду на тих, хто займався аналогічним бізнесом після нього і вигравав справи, проте відстоюючи не право власності на Місяць, а лише авторські права на оригінальну ідею. Цікавим є той факт, що жодного дозволу на привласнення Місяця Хоуп не отримував, а відсутність відповіді на свій лист до ООН він трактував як мовчазну згоду [International Law, 2018].

Проте людство вирішило не зупинятися на ідеї продажу небесних тіл і знову ж таки громадяни США, власники першого «космічного туристичного агентства» Space Adventures Ltd Пітер Діамандіс та Ерік Андерсен з метою ведення видобутку на астероїді заснували компанію Planetary Resources.

Тому логічним є виникнення питання щодо правомірності претензій на астероїд 3 боку приватних компаній, за аналогією привласнення Місяця компанією Деніса Хоупа. 
Для відповіді на це питання, слід вивчати нормативні акти деяких країн, які регулюють їх космічну діяльність. Одним із таких єЗакон про космос, прийнятий Сполученими Штати Америки у листопаді 2015 року, які вирішили не обмежуватися виключно діяльністю у космосі, а вирішили піти далі, розповсюджуючи свій суверенітет на деякі космічні ресурси. Революційним $€$ те, що національний законодавчий акт наділяє громадян США правом володіння, користування, а також розпорядження (продажу) ресурсів небесних тіл та астероїдів. У цьому законі також міститься заборона для суб'єктів приватного права володіти територіями небесних тіл. США вирішили самостійно визначити право власності на ресурси небесних тіл, наприклад, воду і мінерали, незважаючи на те, що Міжнародним Договором про космос не передбачено такого права для жодної країни світу. Прийняттям Закону про космос Сполучені Штати Америки створили підстави для утворення правової колізії з приводу того, чи має хтось взагалі займатися видобутком, володінням і розпорядженням ресурсів небесних тіл та астероїдів, багатих платиною, вольфрамом, залізом і нікелем, і чи може це право стосуватися суб'єктів приватного права.

Тому претензії приватних компаній на небесні тіла до сих пір $є$ предметом дискусії. 3 цього приводу цікавою є думка професора космічного права в Університеті Небраски Лінкольна Франс он дер Данк з приводу того, чи законно зараз приватні компанії займаються видобутком мінералів на астероїдах, який зазначив наступне: «На жаль, Угода про відкритий космос 1967 року залишає деякі сумніви. Тому проти розробки астероїдів протестують ті, хто з якихось причин налаштований негативно. Я дотримуюся думки, що це легально, якщо за процесом наглядає відповідна країна, в даному випадку США».

Проте США не є єдиною державою, яка заявила про свої наміри опановувати ресурси небесних тіл. Свропейське герцогство Люксембург стало другою у світі країною, яка схвалила промисловий видобуток і продаж космічних ресурсів, зокрема, освоєння астероїдів. Так, 1 серпня 2017 року Люксембург прийняв закон, який забезпечив правовий статус видобутку корисних копалин в космосі приватними компаніями [Thailly \& Schneider, 2017].

Лінкольн Франс он дер Данк вважає Закон про космос 2015 року першим кроком до такого регулювання і пропонує розглядати його як запрошення до міжнародного співтовариства виробити глобальний правовий режим. При цьому, коментуючи положення про те, що Угода декларує, що відкритий космос не належить жодній 3 держав, він зазначає, що з цього приводу інколи роблять висновок, що для видобутку ресурсів потрібен міжнародний режим і міжнародна згода, проте наводить досить цікаву аналогію: «У відкритому морі теж немає державного суверенітету, але це нікому не заважало ловити там рибу».

Повертаючись до положень Договору 1967 року, який підписали понад 100 країн, a саме до ст. 2, у якій йдеться, що «Космічний простір, включаючи Місяць і інші небесні тіла, не підлягає національному присвоєнню ні шляхом проголошення на них суверенітету, ні шляхом використання або окупації, ні будь-якими іншими засобами», цілком логічною є думка про те, що космічний об'єкт або його частина не може стати приватною власністю. Проте США та Люксембургу приймаючи закони про видобуток корисних копалин в космосі знову ж таки скористалися прогалиною у Договорі 1967 року, посилаючись на відсутність у ньому положень про видобуток корисних копалин в космосі. 
State Participation in Space Activities: Some Legal Approaches and Implications by Iryna Ryzhenko and Olena Halahan

Слідом за США, 16 листопада 2016 року Японія оприлюднила власний Закон про космічну діяльність, що встановлює порядок видачі дозволів на запуск приватними компаніями космічних ракет, а також використання супутників (далі - Закон про космічну діяльність). Основна ідея закону полягає у тому, що механізм відшкодування збитків за негативні наслідки від космічної діяльності функціонуватиме у тому разі, якщо сума нанесених збитків при аваріях перевищуватиме певний розмір, передбачений для відшкодування.

Нині людство переживає новий етап розвитку космічних технологій під назвою New Space, коли ведеться активна розробка в області орбітального транспортування, польотів до Місяця та Марса, космічного туризму і довгострокового перебування людини в космосі, а також освоєння космічних природних ресурсів. Людство перед собою ставить мету створення надзвичайно розгалуженого «сузір'я» зі штучних супутників для охоплення всієї планети, очищення навколоземного космічного простору від сміття і уламків, дослідження та колонізації Марса, проведення розвідки й освоєння природних ресурсів на астероїдах, а також забезпечення орбітального постачання і обслуговування ефективного видобутку ресурсів і проведення космічних досліджень. При цьому постійно збільшується якісний і кількісний склад учасників космічних відносин, i, оскільки ніхто не може бути застрахованим від помилок, актуальним залишається питання відповідальності цих суб'єктів і відшкодування збитків постраждалим сторонам [Kurasawa, 2018].

Великою проблемою $є$ також можливість застрахувати приватний політ в космос для організацій, що розвивають напрям обслуговування космічних туристів. Нині єдиною можливістю для бажаючих полетіти в космос $є$ відвідування Міжнародної космічної станції за допомогою Space Adventures Ltd і Роскосмоса, проте ці послуги можуть оплатити лише дуже заможні клієнти. При цьому поширюється ідея здешевлення візитів у космос за рахунок суборбітальних туристичних польотів. Але зважаючи на те, що за статистикою 1 рейс зі 100 закінчується аварією, компанії не мають можливості довести безпечність цих польотів для пасажирів, що автоматично породжує неможливість застрахувати такі приватні польоти в космос.

Для ілюстрації актуальності цього питання у нас час, процитуємо спеціаліста 3 міжнародного і космічного права, доктора юридичних наук, професора відділення юридичних досліджень аспірантури Університету Кейо Аокі Сецуком, яка коментуючи закон Про космічну діяльність Японії визначає, що «відповідальність за відшкодування шкоди в разі аваріїлягає головним чином на виконавця запуску навіть в тому випадку, коли проблема сталася через космічний апарат, а не ракету-носія», при цьому зазначає, що це «зможе підвищити конкурентоспроможність японських виконавців космічних запусків, оскільки вона буде вселяти спокій в замовників космічних стартів - користувачів супутників з усього світу». Аокі Сецуком зазначає, що аналогічні положення $\epsilon$ і у французькому законодавстві.

У порівнянні з іншими країнами космічний розвиток Японії відбувався за іншим особливим сценарієм. У 1969 р. парламент Японії прийняв «Резолюцію про мирне використання космосу», відповідно до якої японський космічний розвиток вівся «тільки в мирних цілях», що виключало взаємодію сил самооборони та ядерної енергетики до космічного простору, і передбачалося, що вони повинні утримуватися не тільки від досліджень і розробок, а й від володіння, управління та використання космічних систем. 3 цієї причини космічний розвиток Японії здійснювався виключно в цивільних 
цілях. Що ж стосується використання космосу в цілях оборони, то лише в 1980-і роки було схвалено використання таких послуг як зв'язок і передача даних через комерційні супутники. Таким чином, протягом довгого часу національна оборона і космос не мали точок дотику.

Усі види космічної діяльності регулюються загальними нормами міжнародного космічного права. Проте особливе значення мають прикладні види космічної діяльності, які характеризуються тим, що супутники використовуються не для дослідження космосу, а мають прикладне практичне значення на Землі. Необхідність міжнародноправового регулювання прикладної космічної діяльності зумовлена глобальним характером наслідків цих видів діяльності. Держава проявляє свою правосуб'єктність у тому, що використовує такі супутники для вирішення практичних завдань національної господарської діяльності [von Bencke, 1997: 159].

Слід зазначити, що свобода космосу жодною мірою не може слугувати підставою для ведення діяльності, яка має на меті порушення принципу поваги державного суверенітету, адже під час використання супутників можуть зачіпатися суверенні права і законні інтереси інших держав [Doyle, 1992: 127].

Саме тому з метою міжнародно-правового регулювання прикладних видів космічної діяльності у міжнародному космічному праві склалася система загальновизнаних принципів і норм.

\section{Застосування космічних засобів для дослідження Землі із космосу або дистанційне зондування Землі}

У 1986 році Генеральна Асамблея ООН прийняла Принципи, що стосуються дистанційного зондування Землі з космічного простору, відповідно до яких держави повинні сприяти розвитку міжнародної співпраці в цій галузі.

Проблема ж використання інформації у результаті Д3З із космосу проявляється, виходячи із принципу суверенітету держав над своїми природними ресурсами.

Комплексне використання правової основи діяльності в області Д3З з космосу здійснюється як на міжнародному, так і на національному рівнях. За допомогою ДЗ3 заінтересовані суб' єкти визначають стан елементів суші, океану і атмосфери Землі, вивчають природні ресурси Землі, антропогенні об'єкти і утворення. Вважається, що різновидом Д3З є космічний контроль за дотриманням договорів про обмеження озброєнь і роззброєння. Здатність фотографувати 3 космосу земну поверхню і отримувати відомості про земну поверхню за допомогою обробки розкритих нею променів, які приймаються супутниковою апаратурою, викликала необхідність у міжнародно-правовому регулюванні діяльності як з дистанційного зондування Землі (Д33) так і з використання даних ДЗ3.

Процес Д3З має бути відкритим і здійснюватися на підставі двосторонніх та багатосторонніх угод, відповідно до яких кожній державі, територія якої підлягає Дз3, забезпечуються гарантії доступу до отримання відомостей стосовно іiі природних ресурсів. Державам, територія яких підлягає розвідуванню із космосу, може надаватися доступ до відомостей першочергово і до того моменту, коли вони стануть широко відомими.

Досі не вирішеним є питання про допустимість передачі відомостей про приватних осіб державним органом і про те, чи можуть бути такі відомості доказами в суді. У випадку позитивної відповіді на зазначене питання міг би виникнути ризик для широкого 
State Participation in Space Activities: Some Legal Approaches and Implications by Iryna Ryzhenko and Olena Halahan

застосування Д33 для нагляду за громадянами під приводом дотримання громадського порядку. Логічно постає питання про забезпечення доступу громадян до інформації, що накопичується на них через використання можливостей ДЗЗ у адміністративних органах. При цьому необхідні відомості про зондування мають розглядатися як адміністративна інформація.

Виникає необхідність в удосконаленні міжнародних норм, що регулюють космічну діяльність в області Д33. Такий важливий вид діяльності як Д3З потребує ретельнішої правової регламентації з метою недопущення будь-яких зловживань, для попередження нанесення збитків будь-якій державі або міжнародній безпеці чи природному середовищу нашої планети.

Проблемним питанням є поєднання принципу свободи космічної діяльності iз принципом суверенітету держав над своєю територією, зокрема над природними ресурсами. Д3З чужої території є порушенням принципу суверенітету країн, і особливо може мати негативні наслідки для країн, що розвиваються.

Можна вважати, що спостереження за людьми є можливим за рішенням суду, якщо результати Д3З можуть бути використані у результаті доказу з метою попередження або розкриття злочину.

Що стосується інформації, отриманої у результаті Д33, то іiі доцільно вважати інтелектуальною власністю, що дає можливість власникові зазначеної інформації забезпечити необхідний захист від їі незаконного копіювання і розповсюдження. Проте, зважаючи на специфічність ринку ДЗ3 цією діяльністю можуть одночасно займатися суб’ єкти як публічного, так і приватного права.

Важливим є те, що поза сферою дії принципів Д33 знаходяться супутники нагляду у воєнних цілях. Так держави, які активно займаються космічною діяльністю, у випадку необхідності, завжди можуть за допомогою супутників оглядової розвідки спостерігати за базами в країнах, чия поведінка викликає побоювання. До предмету регулювання принципів Д3З не відноситься зондування ділянок земельної і водної поверхні, що знаходяться під юрисдикцією зондуючої держави. Тобто предметом регулювання принципів Д33 є територія іноземних держав, а також водні і земельні простори за межами національних юрисдикцій держав. При цьому характерною особливістю космічної діяльності $є$ те, що порівняно з найбільш передовими технологічними галузями дуже важко виділити у ній окремо виключно військові функції або лише приватноправові відносини. Саме військові розробки часто служать відправною точкою для розвитку прикладних видів космічної діяльності. Наприклад, супутники комунікаційної системи навігації GPS, забезпечуючи завдання позиціонування, навігації та визначення часу для ВПС США, були розроблені з метою підвищення точності наведення бойових ракет. Проте нині безкоштовні послуги GPS надаються по всьому світу і використовуються у найважливіших сферах життєдіяльності людини.

Що стосується відповідальності держав у сфері Д33, то відповідна діяльність, будучи цілісною у функціональному плані, залежно від міста виникнення поділяється на наземну і космічну.

Космічна відповідальність у сфері Д3З є прямою відповідальністю держав за будьяку національну діяльність у космосі, незалежно від того, якими особами ця діяльність здійснюється.

Щодо питання про режим відповідальності за наземну діяльність Д33 із космосу, то вона залишається відкритим. Зокрема, на підставі ст. 6 Договору про космос 1967 р., 
відповідальність як за космічну, так і за наземну діяльність в області Д3З має бути покладена на державу, під чиєю юрисдикцією ця діяльність проводиться.

При вирішенні питання про природу міжнародно-правової відповідальності в області Д33, розрізняють іiі форми - політичні і матеріальні. Політичну відповідальність за діяльність Д33, що вміщує у собі розповсюдження супутникової інформації на міжнародній арені, нестимуть держави, що санкціонують цю діяльність і здійснюють за нею контроль. Матеріальну відповідальність за збитки, нанесені у результаті передачі отриманої інформації третім особам, варто покладати на національні організації і визначати іï відповідно до процедур, прийнятих у національному законодавстві і у міжнародному приватному праві».

Серйозною проблемою, що виникає у процесі здійснення Д3З є чітке розмежування діяльності супутникового контролю за дотриманням тих чи інших положень, укладених між сторонами угод і шпигунської, розвідувальної діяльності, для якої застосовується досконала апаратура воєнних супутників. Шпигунська (розвідувальна) діяльність несумісна з принципами космічної діяльності.

\section{Безпосереднє телевізійне мовлення через супутники}

У ході розвитку супутникових технологій створювалася техніка, що дозволяла випромінювати з супутника зв'язку сигнал, який міг бути прийнятим безпосередньо на індивідуальні телевізійні приймачі і забезпечувати міжнародне безпосереднє телевізійне мовлення. Необхідність правового регулювання діяльності пов'язаної зі здійсненням міжнародного безпосереднього телевізійного мовлення призвела до прийняття у 1982 р. Генеральною Асамблеєю ООН Принципів використання державами штучних супутників Землі для міжнародного безпосереднього телевізійного мовлення. Роль держави, відповідно до вищезазначеного документа полягає у том, що служба міжнародного безпосереднього телевізійного мовлення може бути створена тільки на основі угод або домовленостей між державою мовлення і державою прийому передач міжнародного безпосереднього телевізійного мовлення.

\section{Використання ядерних джерел енергії у космічному праві}

Обговорюючи питання відповідальності, слід наголосити на тому, що держави несуть міжнародну відповідальність за всю національну діяльність, у тому числі, що здійснюється з використанням ядерних джерел енергії в космосі. Під час міжпланетних польотів, а також при польотах на досить високих орбітах можуть використовуватися ядерні джерела енергії.

Приводом виникнення цього питання послугувала аварія радянського штучного супутника Землі «Космос-954», в результаті якої в 1978 році відбулося радіоактивне зараження північної частини території Канади. Відшкодування збитків, які настають у результаті використанням ядерних джерел енергії в космосі, мають покривати витрати на проведення операцій з пошуку, евакуації та розчистки заражених територій. Держави несуть матеріальну відповідальність за нанесені збитки, що настали в результаті негативних наслідків використання ядерних джерел енергії в космічному просторі.

Заумовизберігання відпрацьованих об' єктів на досить високих орбітах ядерні джерела енергії можуть використовуватися також під час польотів на низьких навколоземних орбітах. За будь-яких умов держави повинні докладати зусиль для захисту людей i 
біосфери від радіологічної небезпеки. Правоздатність держави, яка здійснює діяльність, 3 використанням ядерних джерел енергії в космосі, полягає у тому, що вона проводить експертну оцінку безпеки ядерних джерел енергії до їх запуску в космос, результати якої ще до запуску повинні бути опубліковані і повідомляються Генеральному секретарю ООН. Держава також надає відповідну інформацію у результаті виникнення небезпеки повернення радіоактивних матеріалів на Землю. 3 метою забезпечення міжнародноправового регулювання зазначеного питання у 1992 р. Генеральна Асамблея ООН прийняла Принципи, що стосуються використання ядерних джерел енергії в космічному просторі, які виходять 3 практичної доцільності використання ядерних джерел енергії на борту космічних об'єктів.

\section{Використання геостаціонарної орбіти}

Сьогодні у період надсучасних технологій, коли деякі юристи за завданням НАСА, працюють над питанням підготовки угод та переглядом норм на випадок контакту астронавтів і позаземного життя, в основному космічні юристи все ж таки займаються питаннями правового регулювання супутників, які використовуються для забезпечення потреб телебачення, навігації, інших комерційних, військових та урядових потреб. Окрім стандартних процедурних питань, що виникають у результаті поточного обслуговування супутників, вирішенню вимагають проблеми конфліктів держав на підставі обмеженої кількості місць для цих апаратів, зокрема на геостаціонарній орбіті. Конфлікт інтересів викликаний тим, що країни, що розташовані на екваторі, вважають що володіють правом контролювати небо над своєю територією. Проблема потребує нагального вирішення, оскільки постійно зростає кількість країн, які бажають запустити на орбіту свої супутники, а місця для них стає все менше. У зв'язку з цим проблема правовідносин між державами та їх правосуб’єктності набирають все більшої актуальності у міжнародному праві. Особливо це стосується прикладних видів космічної діяльності.

Так, відповідно до резолюцією Генеральної Асамблеї ООН тисячі сімсот двадцять одна (XVI) від 20 грудня 1961 р. зв'язок за допомогою супутників повинен стати доступним для всіх держав світу, що автоматично означає виключення дискримінації.

Сторони, які бажають запустити на орбіту свої супутники, посилаються на положення Міжнародної конвенції електрозв’язку 1982 року, у якій йдеться про те, що при використанні смуг частот для космічної радіозв'язку члени Міжнародного союзу електрозв'язку враховують, що частоти і орбіта геостаціонарних супутників $\epsilon$ обмеженими природними ресурсами, які належить ефективно i економно використовувати, щоб забезпечити справедливий доступ до цієї орбіти і цим частотам з урахуванням особливих потреб країн, що розвиваються і географічного положення деяких країн. 3 метою запобігання взаємних перешкод і ефективного функціонування координація експлуатації всіх систем супутникового електрозв'язку здійснюється в рамках Міжнародного союзу електрозв'язку. Відповідне положення дублюється у ст. 44 Статуту Міжнародного союзу електрозв'язку, прийнятому у 1992 р. А Комісія $\mathrm{OOH}$ з космосу розробила проект Принципів загального характеру, які забезпечують справедливе використання геостаціонарної орбіти усіма країнами нині і у майбутньому.

Отже, підсумовуючи вищезазначене, приходимо до висновку, що держави повинні узгоджувати між собою напрями своєї космічної діяльності. Незалежно від того, хто здійснює космічну діяльність - урядові органи або неурядові юридичні особи держави, 
держави нестимуть відповідальність за порушення норм міжнародного космічного права несуть. За негативні наслідки космічної діяльності, яка здійснюється міжнародною організацією, відповідальність за це нестимуть як сама організація, так і країниучасники. Порядок реалізації матеріальної відповідальності встановлений Конвенцією про міжнародну відповідальність за шкоду, заподіяну космічними об'єктами, 1972 р., яка вміщує у собі положення щодо відшкодування збитків у випадку позбавлення життя, тілесних ушкоджень або інших збитків для здоров'я, від знищення або пошкодження майна держав, фізичних або юридичних осіб і міжнародних організацій.

У випадку, якщо у результаті правомірною космічної діяльності шкода була завдана іноземній державі або їі фізичним і юридичним особам, обов'язок відшкодування шкоди покладатиметься на державу, яка здійснює або організує запуск космічного об'єкта, а також на державу, з території або установок якої здійснюється запуск об'єкта. Відповідальність у космічному праві носитиме абсолютний характер в разі заподіяння шкоди на поверхні Землі або повітряному судну в польоті. Відповідальність за шкоду, заподіяну космічним об’єктом однієї держави космічному об'єкту іншого в будь-якому місці, крім поверхні Землі, заснована на принципі провини.

Професор Університету Хоккайдо Судзукі Кадзуто, який отримав премію «Санторі» з гуманітарних наук за його книгу «Розвиток космосу і міжнародна політика», роздумуючи про взаємозв’язок космосу і перспектив оборони Японії, вважає, що сучасні оборонні системи неможливо уявити без використання космічного простору, називає космос новою територією військових зіткнень. За тих умов, коли існує можливість безпосередньо з земної поверхні збивати ракетою супутник, актуальною стає проблема правової регламентації можливих навмисних дій із метою руйнування супутників. Таким чином за можливості ризику військового протистояння між розвинутими космічними державами існує ймовірність, що першочерговими об'єктами атаки можуть стати саме космічні системи. У випадку такого нападу майже неможливо встановити, яка сторона є суб'єктом нападу і що насправді відбувається з супутниковими пристроями постраждалої сторони у момент нападу. Цілком логічно, що факт фізичної атаки на супутники та визначити особу атакуючого не те є складним завданням, проте зовсім інакше ситуація виглядає у випадку кібератаки [Кадзуто, 2018].

\section{Висновки}

Таким чином, проаналізувавши питання міжнародної правосуб'єктності держави у реалізації прикладних видів космічної діяльності, доходимо висновку, що саме держава має забезпечувати захист навколишнього середовища, у тому числі, під час здійснення прикладних видів космічної діяльності. Держава, яка має намір займатися космічною діяльністю повинна відповідати наступним критеріям. По-перше, така держава повинна мати затверджені національні екологічні стандарти, обов'язкові до виконання усіма суб'єктами публічного та приватного права, узгоджені із екологічними нормами міжнародного права. Окрім того, держава як гарант національної космічної діяльності, має забезпечувати здійснення процедури відшкодування збитків за наслідки космічної діяльності ії суб'єктів. У зв'язку з цим кожна держава повинна виробити систему національних стандартів за негативні наслідки космічної діяльності, спричинені ії суб'єктами. 3 метою уникнення колізій, і через наявність різних політичних воль, надзвичайно актуальним є прийняття єдиного уніфікованого акту про міжнародну відповідальність держави за 
негативні наслідки у сфері прикладної космічної діяльності, викликані власною діяльністю або діяльністю іiї суб’єктів у сфері. Зазначений уніфікований акт повинен містити у собі систему відшкодування збитків потерпілим у тому разі, якщо негативні наслідки у сфері прикладної космічної діяльності викличуть таку необхідність. При цьому важливим моментом є те, що шкода може бути завдана як державі, яка запускає супутник, так і будь-якій іншій, яка випадково постраждала від наслідків дій, пов'язаних із космічною діяльністю, суб'єктів іншої держави, відшкодування збитків постраждалій стороні має відбуватися у повному обсязі, незалежно від фактору територіальності. Немає різниці, чи були нанесені збитки населенню власної країни, чи представникам іншої країни. Правила відшкодування збитків за негативні наслідки у сфері прикладної космічної діяльності повинні регулюватися особливим родом законодавством — міжнародними угодами про відшкодування збитків за негативними наслідками космічної діяльності, незалежно від того, чи були спричинені ці збитки умисними діями національних суб'єктів космічної діяльності, чи шкода наступила у результаті службової недбалості. На відміну від норм приватного права, де відповідальність найчастіше настає на підставі підтвердженого наміру або недбалості, у космічному праві передбачена абсолютна відповідальність держави за дії та бездіяльність, як власні, так і їі суб'єктів. При цьому для забезпечення відшкодування збитків за негативними наслідками космічної діяльності, національними законодавствами слід передбачити режим обов'язкового страхування від шкоди, завданої третім особам, незалежно від того, чи здійснюється космічна діяльність суб'єктами публічного чи приватного права кожної конкретної країни, оскільки ці збитки мають бути відшкодовані урядом країни, яка здійснює космічну діяльність, і незалежно від того, чи будуть вони виплачуватися за кордоном чи на території цієї держави.

Суб'єкти приватного права для забезпечення космічної діяльності повинні мати фінансові гарантії для оформлення страхування з відшкодування шкоди потерпілим сторонам, при цьому держави як суб'єкти публічного права, наприклад США, Франція та Японія, підтримують розвиток галузі за участю приватних інвестицій наступним чином: у разі виникнення збитків, розмір яких перевищу гарантійну суму уряди додатково вносять кошти аж до певної встановленої урядом суми.

Уряди країн, які зацікавлені у технологічному розвиткові національних космічних галузей, завжди зацікавлені у залученні фінансування, у тому числі й від суб'єктів приватного права. А інвестиційна діяльність, зазвичай, більш жваво розвивається, у країнах, де чітко прописані правила ведення бізнесу, і створений належний режим правового регулювання. Аналізуючи космічні законодавства країн, можна зробити висновок, що існуючий стан із правовою регламентацією міжнародно-правової відповідальності країн за наслідками космічної діяльності, найчастіше визначається можливостями і бажанням країн розширювати цю діяльністю, по-перше, і бажанням підтримання приватних підприємств та їх бізнесу, пов'язаного з космічною діяльністю.

\section{Література}

Кадзуто, Судзуки. Космос как новая территория военных столкновений. 2018. https:// www.nippon.com/ru/in-depth/a06101/

Сэцуко, Аоки. Закон о космической деятельности и деятельность венчурных предприятий: Япония стремится к расширению космического бизнеса. 2017. https://www. nippon.com/ru/currents/d00294/ 
Handbook of Space Law. Edited by Frans Von Der Dunk. Edward Elgar Publishing Ltd., 2015. Kurasawa, Hideto. An overview of Japan's space activities. SpaceTech Asia, August 14, 2018. http://www.spacetechasia.com/an-overview-of-japans-space-activities/

International Law: Contemporary Issues and Future Developments. Edited by Sanford Silverburg, Routledge, 2018.

Doyle, Stephen. Legal Aspects of Space Commercialization. Space Law: Development and Scope by Nandasiri Jasentuliyana. Praeger/International Institute of Space Law, 1992.

von Bencke, Matthew. The Politics of Space: A History of U.S.-Soviet/Russian Competition and Cooperation in Space. Westview Press, 1997.

\section{References}

Kadzuto, Sudzuky. Kosmos kak novaia terrytoryia voennыkh stolknovenyi. 2018. https:// www.nippon.com/ru/in-depth/a06101/

Sэtsuko, Aoky. Zakon o kosmycheskoi deiatelnosty y deiatelnost venchurnokh predpryiatyi: Yaponyia stremytsia k rasshyrenyiu kosmycheskoho byznesa. 2017. https://www. nippon.com/ru/currents/d00294/

Handbook of Space Law. Edited by Frans Von Der Dunk. Edward Elgar Publishing Ltd., 2015.

Kurasawa, Hideto. An overview of Japan's space activities. SpaceTech Asia, August 14, 2018. http://www.spacetechasia.com/an-overview-of-japans-space-activities/

International Law: Contemporary Issues and Future Developments. Edited by Sanford Silverburg, Routledge, 2018.

Doyle, Stephen. Legal Aspects of Space Commercialization. Space Law: Development and Scope by Nandasiri Jasentuliyana. Praeger/International Institute of Space Law, 1992.

von Bencke, Matthew. The Politics of Space: A History of U.S.-Soviet/Russian Competition and Cooperation in Space. Westview Press, 1997. 